\title{
Research on the Surface Water Quality in Mining Influenced Area in North-Western part of Romania
}

\author{
Irina Smical ${ }^{\mathrm{A}^{*}}$, Adriana Muntean ${ }^{\mathrm{B}}$, Eugen Nour ${ }^{\mathrm{C}}$ \\ Received: September 19, 2014 | Revised: January 29, 2015 | Accepted: February 28, 2015
}

\begin{abstract}
The paper highlights the current situation of the quality of surface water in the areas influenced by mining activities in the north-western part of Romania. In this respect a series of investigations have been conducted regarding the contamination with heavy metals of the water of the Someş and Tisa hydrographic Basins, which cover the northern part of Maramures County and the south-western area of Maramures County, respectively.

The results of the comparative research refer to the period between 1999 and 2011 and reveal the specific heavy metal ions of mining activity: $\mathrm{Fe}, \mathrm{Mn}, \mathrm{Zn}, \mathrm{Cu}, \mathrm{Pb} \mathrm{Cd}$ and $\mathrm{Ni}$, as well as the water $\mathrm{pH}$. The presented values as annual average values reveal an increase in several heavy metals after the closure of mines, which is due to the lack of effectiveness of the closure and of the conservation of the mine galleries, as well as of the impaired functioning of the mining wastewater treatment plants.
\end{abstract}

Key words: surface water, heavy metals, mining, tailing pond, Romania.

\section{Introduction}

The presence of heavy metals in the aquatic environment represents an intensely studied issue. As it is known, there is already a natural background source of elements to which others are added from anthropic and anthropogenic sources (Macklin, et al., 2006; Hudson-Edwards, 2003; Dawson, Macklin, 1998; Miller, 1997). The sources of water pollution are various but the mining activity has the highest impact, which means not only the exploitation but also the processing of ores.

The tailings generated by these activities, stationed in waste dumps and poorly waterproofed tailing ponds are capable of damaging the surface and underground water by acid drainage (Sima, et al., 2008; Zobrist, et al., 2009).
Being an area with major mining impact, the Maramures County has attracted the interest of researchers to assess the mining influence on environmental factors and human health. Major attention was given to the mining impact on the quality of water, and the content in heavy metals (cadmium, lead, copper, manganese, zinc, iron, arsenic etc) using various investigation techniques (Bird, et al., 2003; Macklin, et al., 2006; Kraft, et al., 2006; Roman, et al., 2008).

To highlight the comparative evidence of surface water quality from the mining influence areas within the Maramures County, several researches were made regarding the heavy metals contamination degree in the two hydrographic Basins Someş and Tisa within the territory of the county, which cover the northern

A Department of Resources, Geodesy and Environment, Faculty of Mineral Resources and Environment, Technical University of Cluj-Napoca, North University Centre of Baia Mare, 62A Victor Babeş Street, Baia Mare City, Maramures County, România, irina.smical@yahoo.com

B Maramures Water Management System, Someș-Tisa Basinal Water Administration, 2 Aleea Hortensiei, Baia Mare City, Maramures County, Romania, adriana1567_muntean@yahoo.com

c Department of Environmental Sciences, Faculty of Environmental Science and Engineering, Babeş-Bolyai University of ClujNapoca, 30 Fântânele Sreet, Cluj-Napoca City, Cluj County, România, eugen.nour@yahoo.com

* Corresponding author: Irina Smical, e-mail: irina.smical@yahoo.com, mobile: 0040-740000345, tel/fax:0040-262276153 
part (Tisa Basin) and the south-western part (Someş Basin), respectively. Six sections were investigated in the Someş Basin and four in the Tisa Basin.

Maramures County is famous for its mining activities which were carried out until the end of 2006 when the mining extraction and processing activities were banned. Currently 17 tailing ponds and about 300 waste dumps are inventoried for Maramures. Of those 17 tailing ponds 1 is still active but has the activity temporarily suspended, and the others are already conserved or under conservation process (NCPBM Remin SA, 2014).

The research results refer to 1999, 2007, 2009 and 2011, and reveal the mining specific heavy metals such as $\mathrm{Fe}, \mathrm{Mn}, \mathrm{Zn}, \mathrm{Cu}, \mathrm{Pb}, \mathrm{Cd}, \mathrm{Cr}, \mathrm{Ni}$ and water $\mathrm{pH}$ both during the exploitation of mines (1999-2007) and after the shutting down of the mining activity (2009, 2011). These values represent the annual average of the monthly analyses outcomes. To comparatively highlight these concentrations, graphical representations were made for every element and hydrographic Basin. These results were compared with the maximum allowable values laid down by the Romanian legislation (Minister Order no. 161/2006) regarding the quality of surface water. The obtained data revealed exceeding of the maximum allowable values of several heavy metals even after the shutdown of the mining activity, which might be explained by the insufficient actions of closing and rehabilitation of mining galleries, and also by the faulty functioning of the wastewater plants.

\section{Methods and data}

The investigations are made for the period 1999-2011, more specifically for 1999, 2007, 2009 and 2011. Year 1999 is representative for the active mining exploitation and ores processing in the County, and 2007 represent the year of the end of the mining activity in the County. Years 2009 and 2011 are indicators for the mining perimeters shutdown and rehabilitation degree.

\section{Considerations on the Maramures County hydrogeology and mining}

The Maramures County is situated in the northern part of Romania (Figure 1) and covers about $6,215 \mathrm{~km}^{2}$ (Retegan, et al., 1980). It partially comprises two major hydrographic Basins: the Tisa Basin (with Tisa as the main river) and the Someş Basin (with Someș as the main river) which form together the Someş-Tisa Basin.

The Romanian Tisa hydrographic Basin having a total area of $4,540 \mathrm{~km}^{2}$ is bordered to the north by Păduroşi Carpathian Mountains (Ukraine), to the south-east by the Maramuresului Mountains, to the south-west by Oaşului Mountains, and to the south by the Maramuresului Depression. (Ministry of the Environment, 1992).

Besides the Tisa River and Someș River, the hydrographic network of the Maramures County is also represented by other main rivers, as: Vişeu River, Iza River and Săpânţa River which flow into the Tisa River, respectively Lăpuş River and Bârsău River which flow into the Someş River. (Posea, et al., 1980).

Tisa River springs from Păduroşi Carpathians Mountains, crosses the northern part of the Romanian territory making up the $62 \mathrm{~km}$ natural border between Romania and Ukraine, farther crosses Hungary and flows into the Danube River on Serbian territory (Ministry of the Environment, 1992).

On the territory of the Maramures County the Tisa River captures a series of surface waters originated from the western slopes of the Maramures Mountains, the northern slope of Rodnei Mountains and Lăpuş area, the northern and eastern side of Oaş-GutâiŢibleş eruptive, respectively. On leaving the Maramures Mountains, the Tisa River captures the Vişeu River, the Iza River, and the Săpânţa River (Figure 1) (Ujvari, 1972).

The Someş hydrographic Basin covers $15,740 \mathrm{~km}^{2}$ (with 403 rivers). The middle part of the Someş River runs through the south southwest of the Maramures County on $50 \mathrm{~km}$ between Benesat and Seini, farther crosses the north-west of Romania and flows into the Tisa River on the territory of Hungary (Ministry of the Environment, 1992; Posea, et al., 1980). The most important Someş tributary in the Maramures County is the Lăpuş River (Figure 1) which collects, beside other rivers, the mining polluted Strâmbu-Băiuţ and Botizu tributaries. In the Baia Mare City, the Lăpuş River receives the Chechiş River and Săsar River and downstream, the Băiţa Valley water (Figure 1) (Posea, et al., 1980).

The Maramures County is geologically characterized by non-ferrous mineral accumulations containing gold-silver ores and polymetalliferous ores which provided the opportunity for mining activities in some exploitations near the following settlements: Ilba, Nistru, Băiţa, Baia Sprie, Şuior, Cavnic, Băiuţ, Poiana Botizei, Țibleş, Baia Borşa (Gura Băii, Colbu, Burloaia mining exploitations) and Vişeu de Sus (Măcârlău, Novicior, Catarama, Ivăşcoaia mining perimeters) (Figure 1) (Bălănescu, 2002; NCPBM Remin SA, 2014). Also remarkable is the presence of copper mineralizations in Nistru, Baia Borşa - Măgura, Vişeu (Măcârlâu and Catarama), the gold-silver mineralizations at Săsar mining perimeter (Valea Roşie Mine, Borzaş Mine, Sofia Mine, Dealul Crucii Mine), Şuior and Băiţa mining perimeters (Figure 1). Iron and manganese ores were identified at Răzoare settlement and Valea Vaserului area (Bălănescu, et al., 2002: 
Smical et al., 2013). The entire waste rock volume removed from the opening mines is about 40 million $\mathrm{m}^{3}$ and is deposited in mining dumps and the tailings resulted from the ore processing; these represent about 67 million $\mathrm{m}^{3}$ and are deposited on the tailing ponds (NCPBM Remin SA, 2014).

At the end of 2006 the extraction and processing activity of non-ferrous and precious ores was banned and the mining perimeters started to be rehabilitated and conserved, yet often superficially and ineffectively (sometimes without the slope angle correction and adequate drainage) (Ministry of Economy, 2014; Vasilescu, et al., 2012).

\section{Investigated hydrographic sections in Maramures County}

To assess the mining perimeters influence on the flowing surface waters within the Maramures County, samples were taken monthly in 10 sections of the Someş-Tisa hydrographic Basin (4 sections in the Tisa hydrographic Basin and 6 sections in the Someş hydrographic Basin) within the Maramures County territory (Figure 1), as follows:

Tisa Hydrographic Basin sections (Figure 1) (from upstream to downstream):

a) Cisla River - Baia Borşa City downstream

b) Vişeu rier - Moisei village downstream

c) Vişeu River - Bistra village downstream

d) Tisa River - Teceu Mic village

By the Bistra village, the Vişeu River drains the waters of Cisla River, Novăţ Roșu River, Vinului Valley, Morii Valley, Crasna River, Ruscova River, and their tributaries (fig. 1). The water quality of these tributaries is influenced by the mining wastewaters originated from the Borşa mining perimeter (Cornu Nedeii, Dealul Negru, Burloaia, Gura Băii, Toroiaga mining exploitations), as well as from wastewaters unpurified with sediments and heavy metals from mining waste dumps and Colbu, D1, D2, D 3 tailing ponds, and Baia Borşa ore Processing Plants, respectively (NCPBM Remin SA, 2014). Moreover, in March 2000, the failure of Novăț Roșu tailling pond generated about $100000 \mathrm{~m}^{3}$ of contaminated water with cyanide and heavy metals and about 20000 tonnes of mineral-rich solid waste which flowed into the Novăt Roșu River and farther (Bird, et al., 2008; Macklin, et al., 2003).

The sampling section of the Tisa River near the Teceu Mic village is located in north-western part of the Maramures County, at the border with Ukraine and SatuMare County, and very far from the other three sections. The water quality in this hydrographic section might be influenced by the water quality from upstream, especially from Viseu River but also from Iza River and Săpânţa River with their tributaries (Figure 1).
Someş Hydrographic Basin sections (Figure 1) (from upstream to downstream):

a) Lăpuş River - downstream of Răzoare village The water quality in this section is influenced by the potentially polluted water originated from the Băiuţ mining perimeter with mining exploitations: Răzoare, Ţibleş-Tomnatec (including the mining waste dumps) (NCPBM Remin SA, 2014).

b) Cavnic River - Copalnic village

The water quality of Cavnic River in this section might be influenced by the Cavnic mining perimeter including the Plopiş-Răchiţele tailing ponds. As it discharges into Lăpuş River near Între-Râuri hamlet (Coaş village), the Cavnic River water quality is influenced by the potentially polluted waters from Breiner mining perimeter - Băiuţ mine, Cisma mining perimeter including the mining waste dumps (NCPBM Remin SA, 2014).

c) Săsar River - downstream of Baia Mare City The Săsar River water quality in this section is influenced by the tributaries which fed the Săsar mining perimeter (near Baia Mare City) and from upstream by the mine wastewater from Şuior mine, Baia Sprie mine, Herja mine and Flotaţia Centrală Processing Plant (including the mining ore deposits). Thereto the water contamination was added in January 2000 when the dam of the Aurul tailing pond was broken and almost $100000 \mathrm{~m}^{3}$ of contaminated water with high concentration of cyanide and heavy metals released and flowed into Lăpuș and Someș rivers impairing their water quality (Macklin, et al., 2003).

d) Lăpuş River - downstream of Buşag village This River section might be influenced by the Săsar River quality which makes a jonction with Lăpuş River upstream, which might also be affected by the water quality from the Săsar mine (especially by discharging mining water from Ioachim gallery, Lobkovitz gallery, Cuza Vodă gallery), as well as from mining ore deposits near the Flotatia Centrală Ore Processing Plant (NCPBM Remin SA, 2014).

e) Someş River - Cicârlău village

The quality of this River near Cicârlău village might be influence by the mining wastewater from Ilba mining perimeter with Purcăreţ, Aluniş, Fata Mare, Venera, Firizan, Mihai-Nepomuc, Valea Roşie, Valea Băii - Nord mining exploitations, as well as by the mining water from Nistru mining perimeter ("9 mai" mine, "11 iunie" mine), and Băiţa mining area with Tyuzosa mine, Emerica mine, Ludovica mine, Galbena 
mine, Mihai Dumbravă mine, and Câmpurele wastewater treatment plant (NCPBM Remin SA, 2014).

f) Someş River - Ulmeni village

The waters in this section of the river Somes at Ulmeni City could be influenced both by the quality of the tributaries from the Maramures
County area (Figure 1) and by the upstream tributaries from the south-west belonging to other counties. These tributaries might also be affected by the quality of discharges from the mining area Rodna (Bistriţa Năsăud) where complex non-ferrous ores were exploited until 2006.

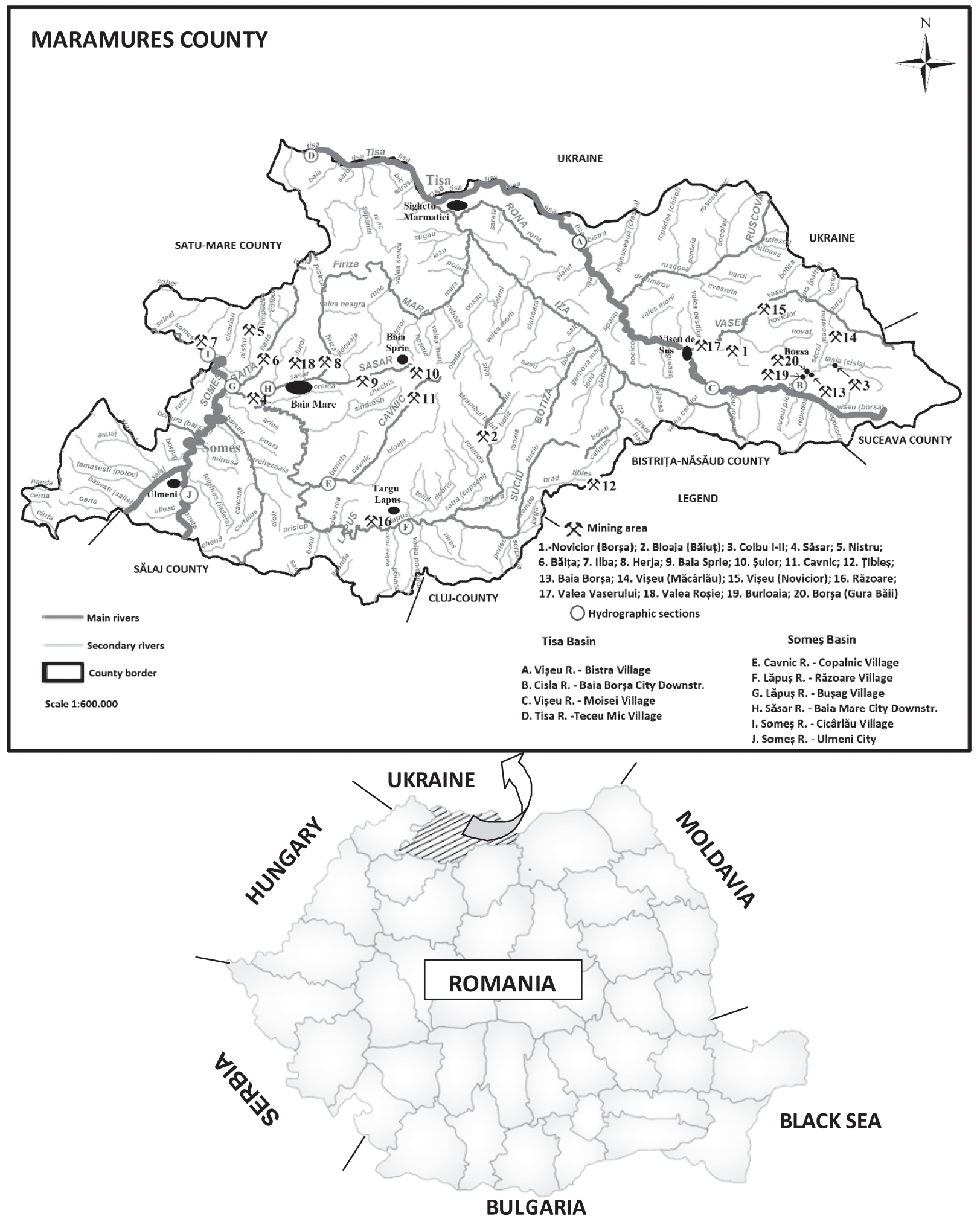

Figure 1. The surface water flows and mining perimeters of Maramures County (Romania) 


\section{Sampling and laboratory}

The collection of water samples to determine the metal content was carried out in polyethylene containers, previously washed with nitric acid 1:1, and then rinsed with ultrapure water.

Because it was intended to determine the dissolved heavy metals from the samples, these were filtered in situ by a filtering system made of a membrane with the nominal pore diameter of $0.45 \mathrm{~mm}$. After filtration, the water samples were immediately acidified with nitric acid at a $\mathrm{pH}<2$.

The analysis of iron, zinc and manganese metals was made by atomic adsorption spectrophotometry, by flame atomization based on the following standards: SR 13315:1996 for Fe, SR 8662-2:1997 for Mn, and SR ISO 8288:2001 for Zn, and atomization in graphite oven. Determination for $\mathrm{Cu}, \mathrm{Cr}, \mathrm{Pb}, \mathrm{Ni}$ and $\mathrm{Cd}$ was made by calibration curves using the AAWinLab soft belonging to Perkin Elmer atomic adsorption spectrophotometer based on the following standards: SR ISO 9174:1998 for Cr, SR EN ISO 5961:2002 for Cd, SR EN ISO 15586:2004 for trace elements (Cu, $\mathrm{Pb}$ and $\mathrm{Ni})$.

The water samples subjected to atomic adsorption spectrophotometry analysis were digested with $1 \mathrm{~cm}^{3}$ of concentrated nitric acid, $0.25 \mathrm{~cm}^{3}$ of $\mathrm{H}_{2} \mathrm{O}_{2} 30 \%$ solution for $100 \mathrm{~cm}^{3}$ water sample to minimize the organic matrix interference.

The analysis by atomic absorption spectrophotometry in graphite oven allows determination of trace concentrations, i.e. ppb order, from acidic water samples $\left(1 \mathrm{~cm}^{3} \mathrm{HNO}_{3}\right.$ concentrated at $100 \mathrm{~cm}^{3}$ filtered sample). The interferences removal is achieved by the addition of matrix modifiers.

\section{Results and discussions}

The analyses results expressed by concentrations of iron, manganese, zinc, copper, lead, cadmium, nickel and $\mathrm{pH}$ respectively, represent annual averages of the monthly concentrations. The values were compared with quality class values provided by Romanian regulations, namely the Minister Order no. 161 from 2006 on the quality state of surface waters.

In the Tisa hydrographic Basin, the Cisla River in the section downstream of Baia Borşa City, presents the highest iron concentrations (dissolved forms) exceeding even the 3 rd water quality class for years 2007 , 2009 and 2011 (Figure 2) (Minister Order no. 161/2006).

Of the four investigated hydrographic sections, the highest iron concentrations are noticed on the Cisla River downstream of Baia Borşa City (Figure 2). This might be explained by the influence of the Baia Borşa mining perimeters (Cornu Nedeii, Dealul Negru, Burloaia, Colbu, Gura Băii, Toroiaga mining exploitations) especially with the mining wastewaters uploaded with heavy metals and sediments from Colbu, D1, D2, D3 mining dumps, as well from the Baia Borşa Ores processing plant.

Referring to the Someş hydrographic Basin the situation is similar with that one in the Tisa Basin regarding the iron concentrations in 1999 and 2007. One can notice that in 2009 and 2011 the iron concentration decreased (Figure 2). The highest iron concentrations were registered for Săsar River downstream of Baia Mare City and might be explained by the intake of the polluted water from Săsar mine cumulated with upstream discharges of the Nistru mine, Băiţa

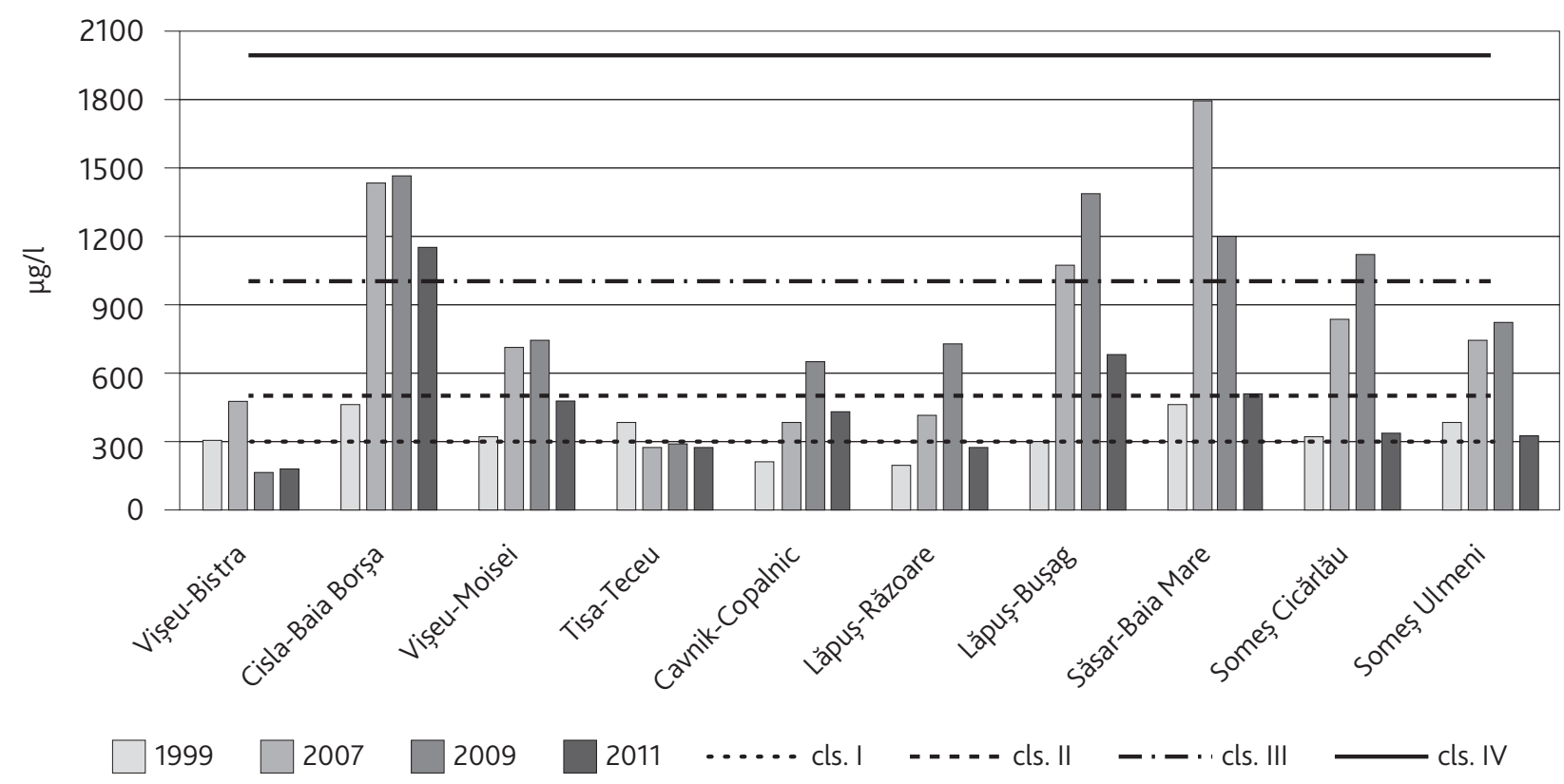

Figure 2. Concentration of total iron $\left(\mathrm{Fe}^{2+}+\mathrm{Fe}^{3+}\right)$ in Tisa Basin and Someș Basin in 1999-2011 period 


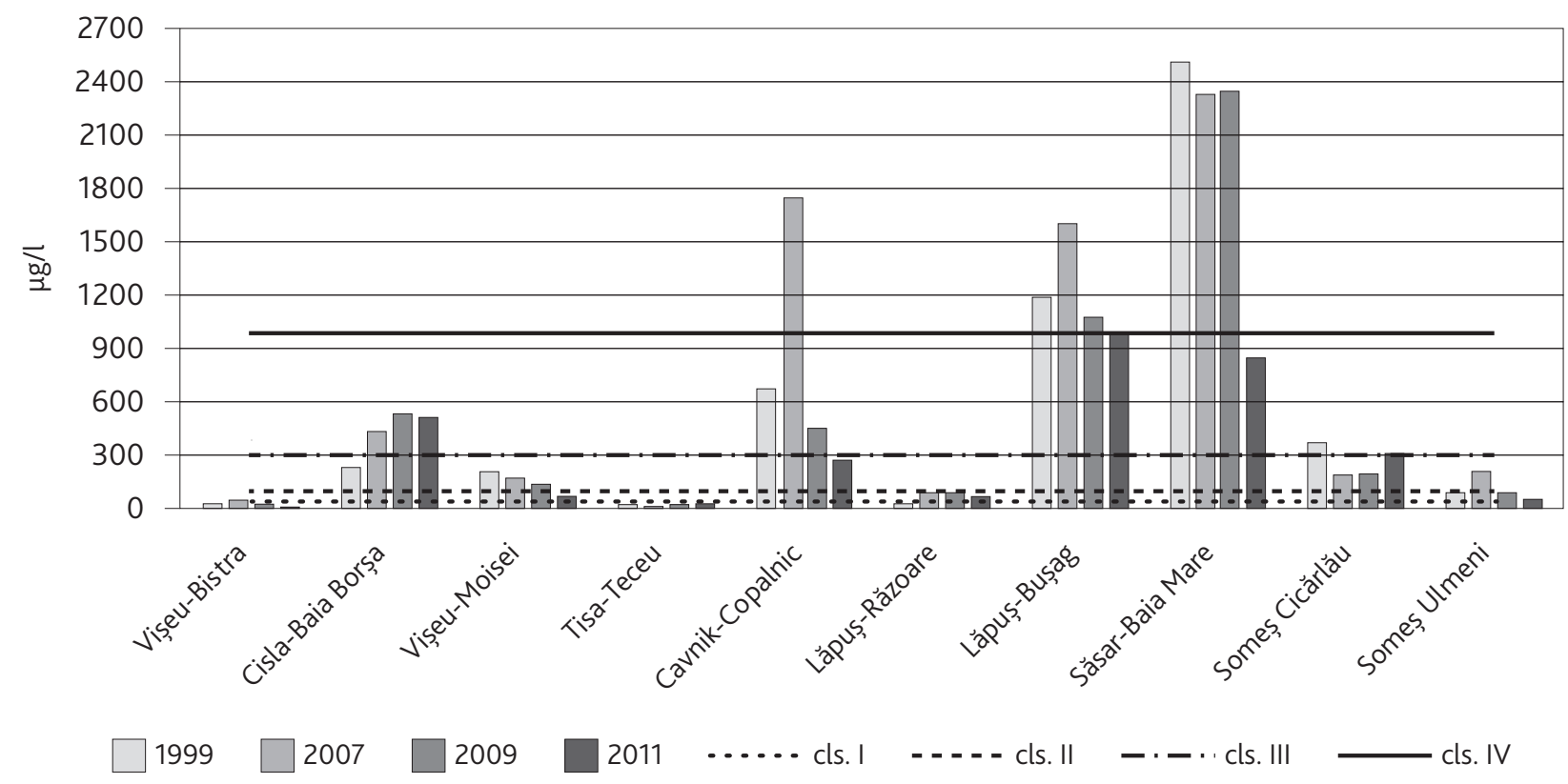

Figure 3. Concentration of total manganese $\left(\mathrm{Mn}^{2+}+\mathrm{Mn}^{7+}\right)$ in Tisa Basin and Someș Basin in 1999-2011 period

mine, Şuior mine, Herja mine and also from Flotaţia Centrală Ores Processing Plant (Figure 1).

The manganese concentrations in the Tisa hydrographic sections register significant increases for Cisla River downstream of Baia Borşa City during the entire investigated period (Figure 3). This might be explained by the major intake of wastewaters originated from the Borşa mining exploitations including the Baia Borşa Ores Processing Plant (Figure 1).

Referring to the Someş hydrographic sections the highest Mn concentrations were noticed for 1999, 2007 and 2009 on the Săsar River downstream of Baia Mare City (Figure 3). This might be due to the intake of polluted waters discharged by the Săsar mine in addition to those from upstream originated from Herja and Şuior mining exploitations, as well as from the Flotaţia Centrală ores processing plant (Figure 1).

With the exception of 2011, during the entire investigated period the manganese concentration in the Săsar River downstream of Baia Mare City was included in the $5^{\text {th }}$ water quality class (Minister Order no. 161/2006) (Figure 3).

The zinc concentrations evolution in the period 19992011 for the hydrographic sections in the Tisa Basin shows the highest increase for Cisla River downstream of Baia Borşa City highlighting the year 2007 when the

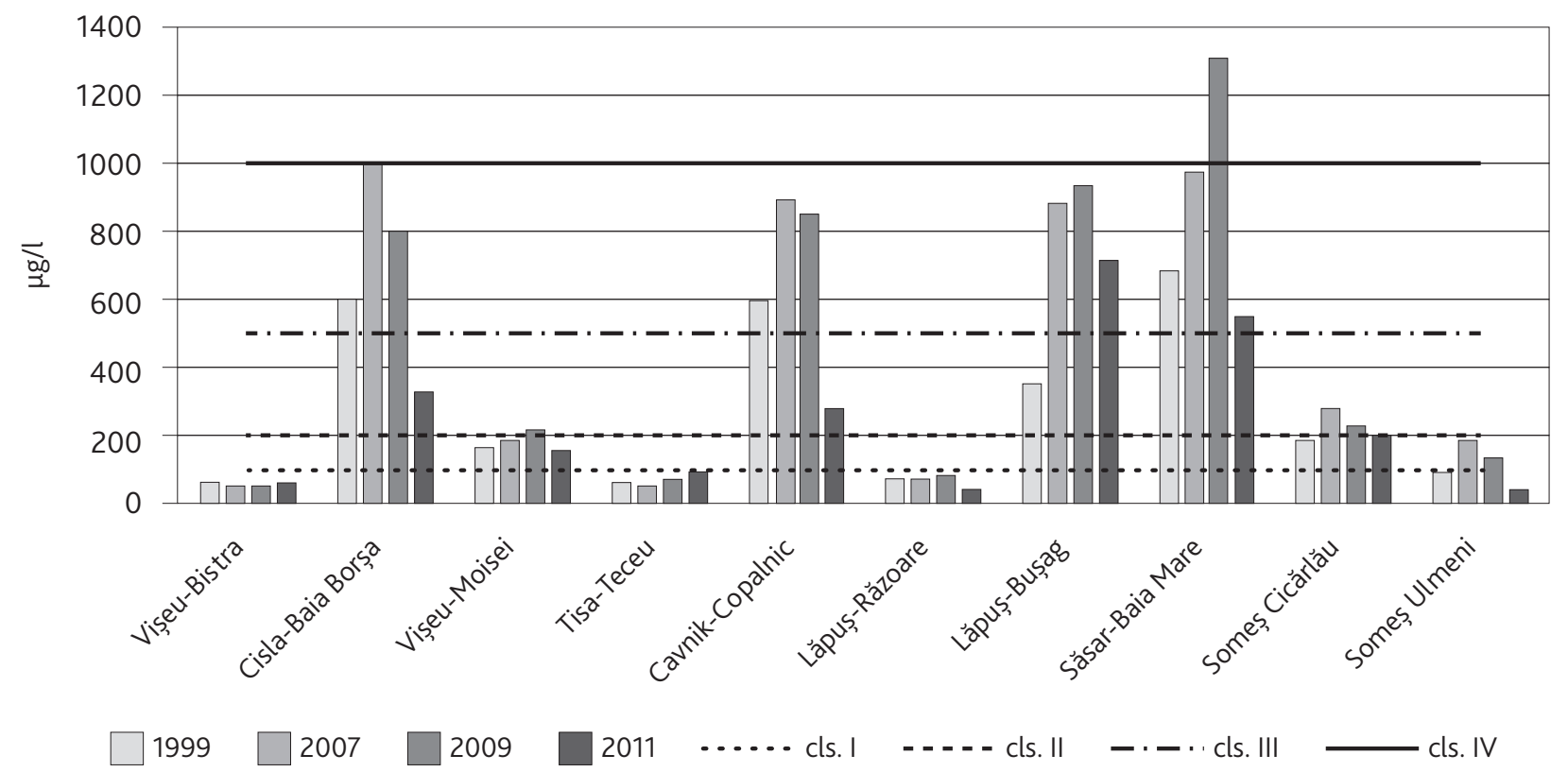

Figure 4. Concentration of zinc $\left(\mathrm{Zn}^{2+}\right)$ in Tisa Basin and Someș Basin in 1999-2011 period 


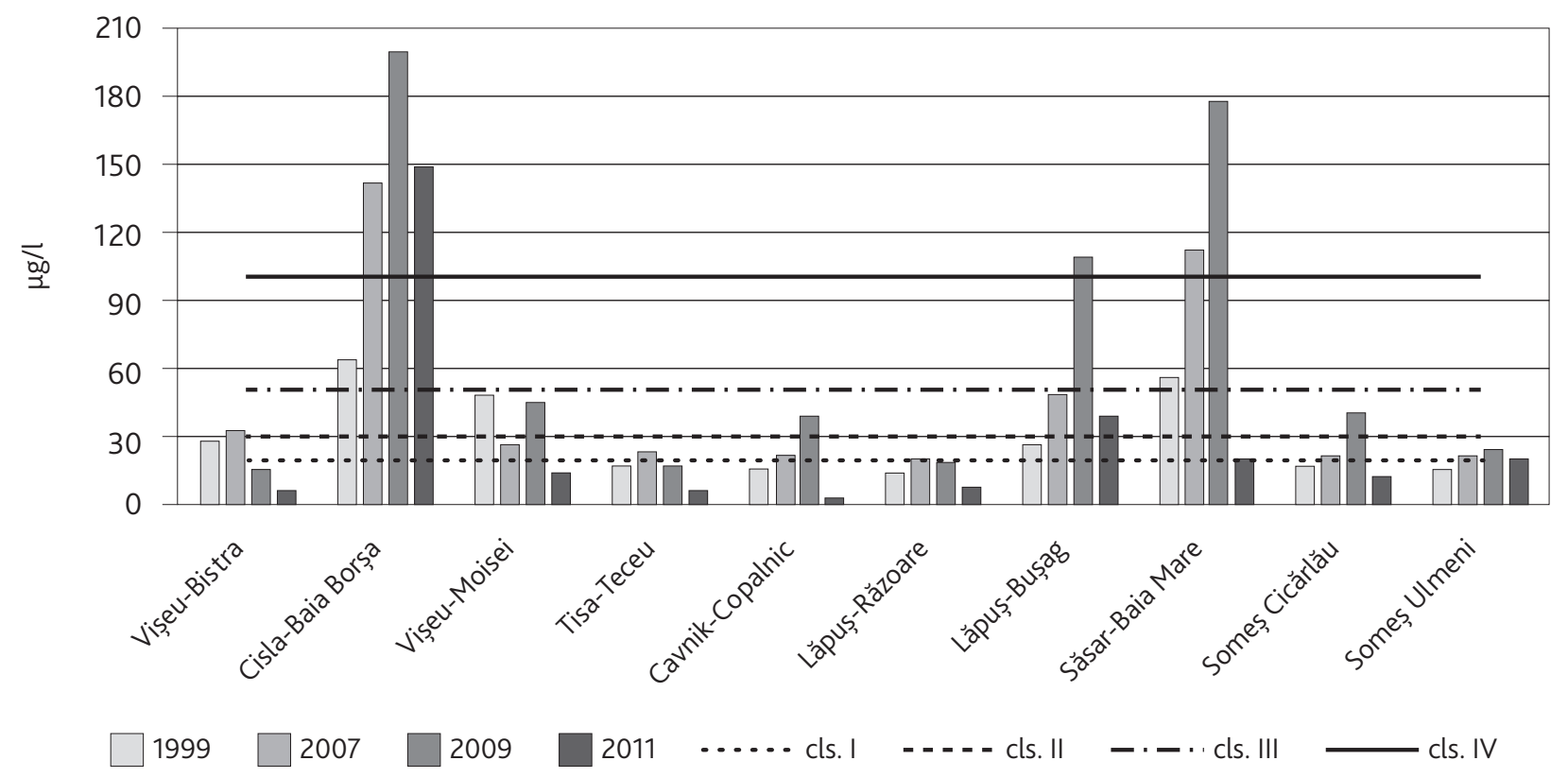

Figure 5. Concentration of copper $\left(\mathrm{Cu}^{2+}\right)$ in Tisa Basin and Someș Basin in 1999-2011 period

zinc concentration value reached the $4^{\text {th }}$ water quality class (Minister Order no. 161/2006) (Figure 4).

For the Someş Basin hydrographic sections major increases of zinc concentrations were noticed especially for 2007 and 2009 in most of the investigated sections; the Săsar River downstream of Baia Mare City, Cavnic River at Copalnic village and also Lăpuş River at Buşag village are highlighted. In all these three hydrographic sections, for 2007 and 2009 the $3^{\text {rd }}$ water quality class was exceeded (Figure 4 ). This framing in a lower water quality level might be explained by the existence of polluted water discharging from the upstream mining exploitations.
An increase in the concentrations of copper in the Tisa Basin sections is noticed mainly in 2007, 2009 and 2011. For all these three years the Cisla River downstream of Baia Borşa City has the water quality over $4^{\text {th }}$ water quality class (Figure 5 ). This is due especially to Baia Borşa discharging mining wastewater.

For the Someş hydrographic Basin the increase of copper concentrations is highlighted for 2007 and 2009 especially for Săsar River downstream of Baia Mare City where for this indicator the $4^{\text {th }}$ water quality class is exceeded (Figure 5) (Minister Order no. 161/2006). This is due to the wastewater intake from the upstream mining exploitations and ore processing plants.

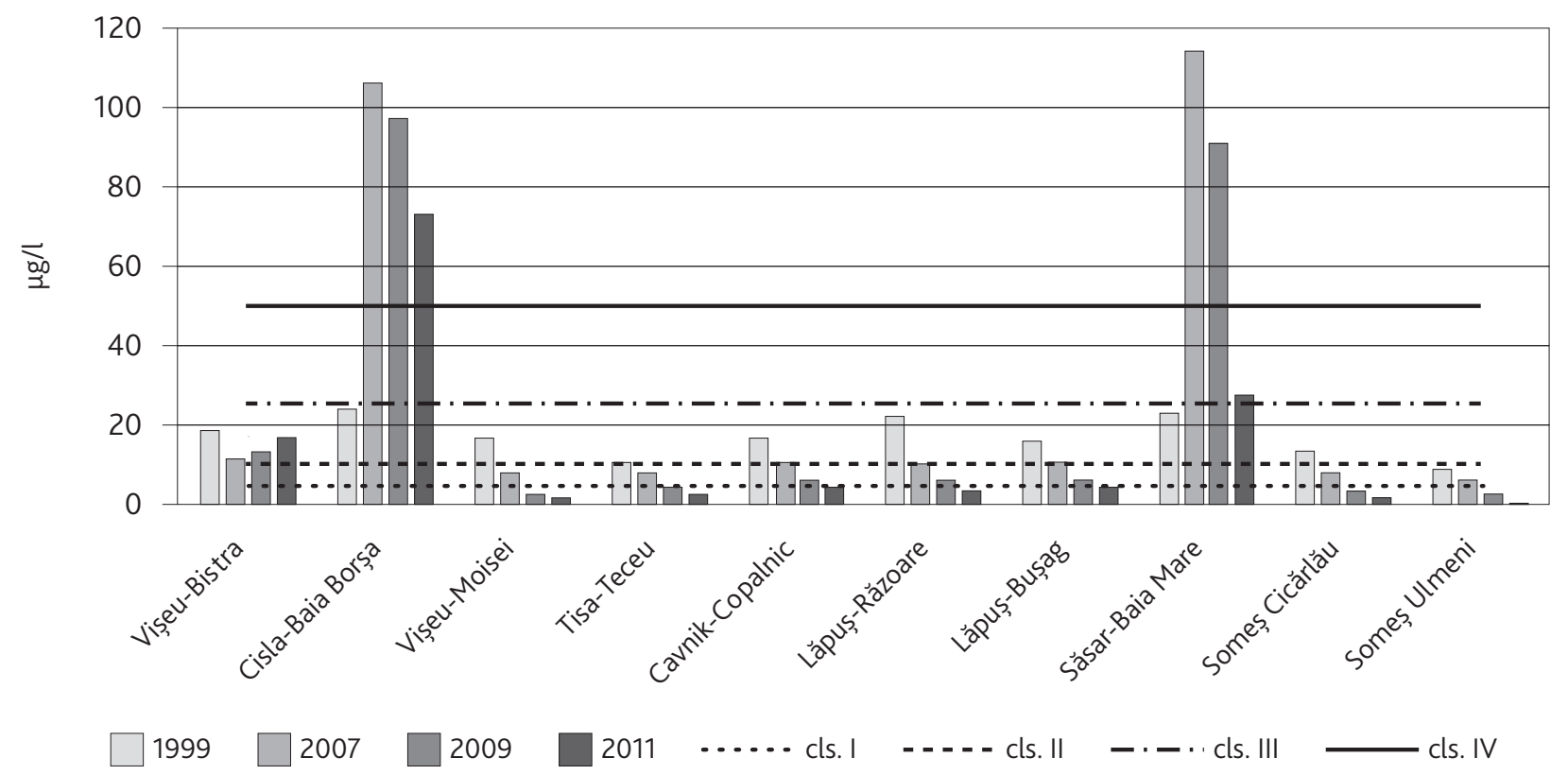

Figure 6. Concentration of lead $\left(\mathrm{Pb}^{2+}\right)$ in Tisa Basin and Someș Basin in 1999-2011 period 


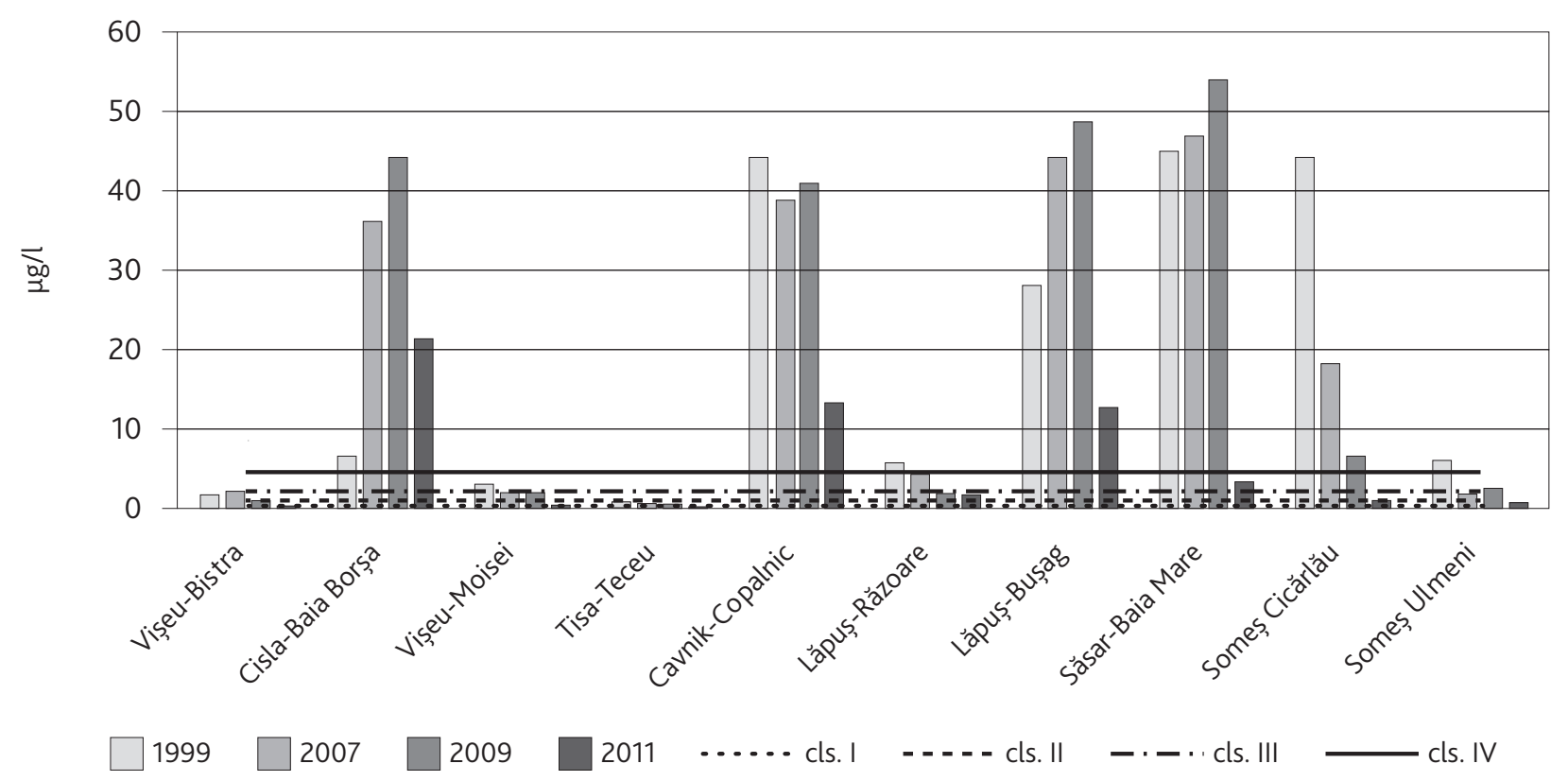

Figure 7. Concentration of cadmium $\left(\mathrm{Cd}^{2+}\right)$ in Tisa Basin and Someș Basin in 1999-2011 period

A major increase is noticed for lead indicator for 2007, 2009 and 2011 for the Cisla River downstream of Baia Borşa where it exceeded the $4^{\text {th }}$ water quality class (Figure 6) (Minister Order no. 161/2006). This might be due to the intake of waters polluted with heavy metals from the former mining exploitations and ore processing plants from Baia Borşa area.

There are also significant increases of lead concentrations in the Someş hydrographic Basin especially at Săsar River downstream of Baia Mare City section where for 2007 and 2009 the $4^{\text {th }}$ water quality class was exceeded (Figure 6). Similar values for cadmium have been reported by Levei, et al., (2008) for the Lăpuș and its tributaries Cavnic and Săsar. The Cd values ranged between 2.2-83 $\mu \mathrm{g} / \mathrm{l}$ for Cavnic River and between 1.6-18 $\mu \mathrm{g} / \mathrm{l}$ for Săsar River (Levei, et al., 2008). This might be due to the upstream mining waters especially from the Şuior mine, Herja mine and Baia Sprie mine, as well as from the Flotaţia Centrală Ore Processing Plant.

For cadmium there are major differences among the investigated sections in the Tisa hydrographic Basin within the Maramures County area. For 2007, 2009 and 2011 important increases of this metal are registered especially in sections of Cisla River downstream of Baia Borşa City, which leads to the framing of water

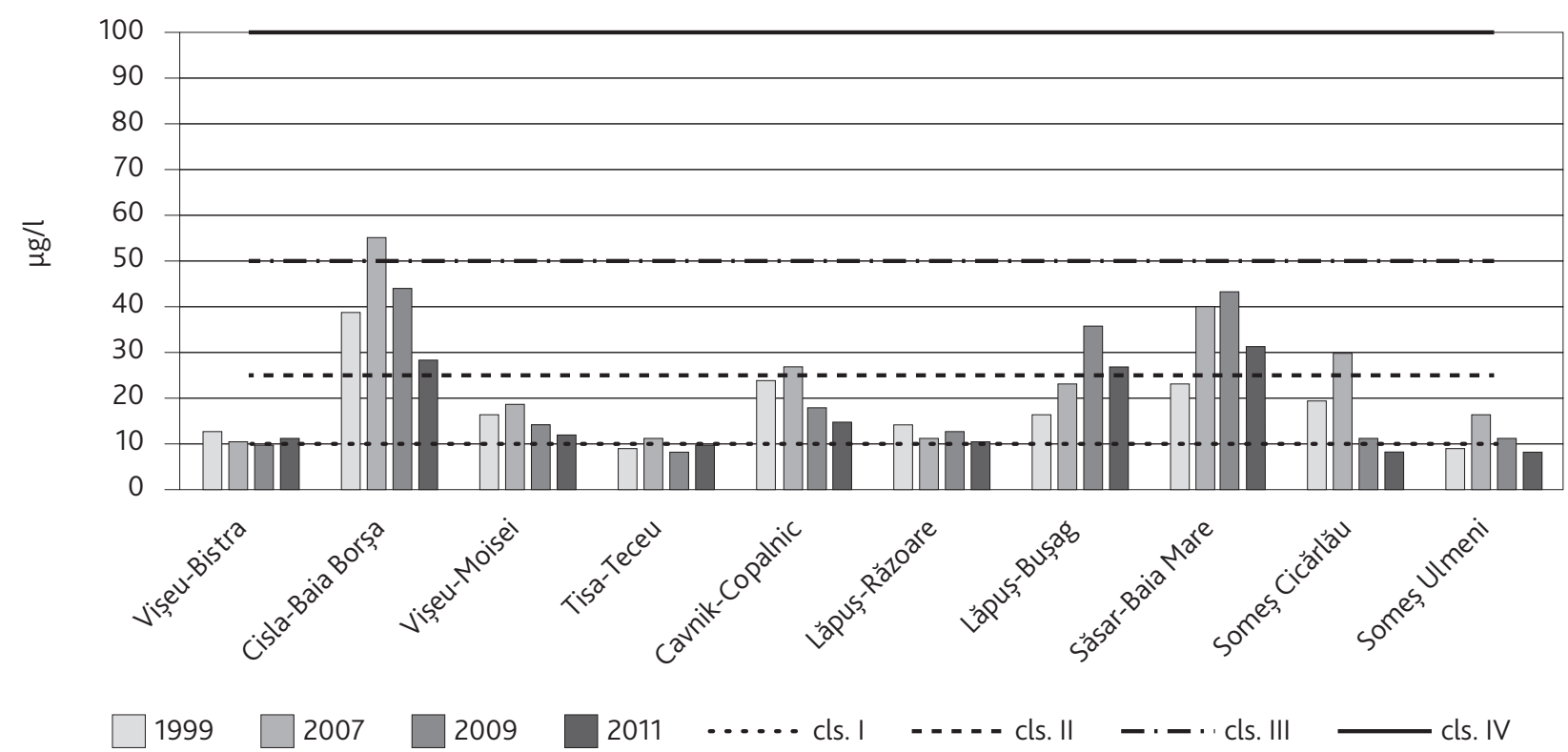

Figure 8. Concentration of nickel $\left(\mathrm{Ni}^{2+}\right)$ in Tisa Basin and Someș Basin in 1999-2011 period 


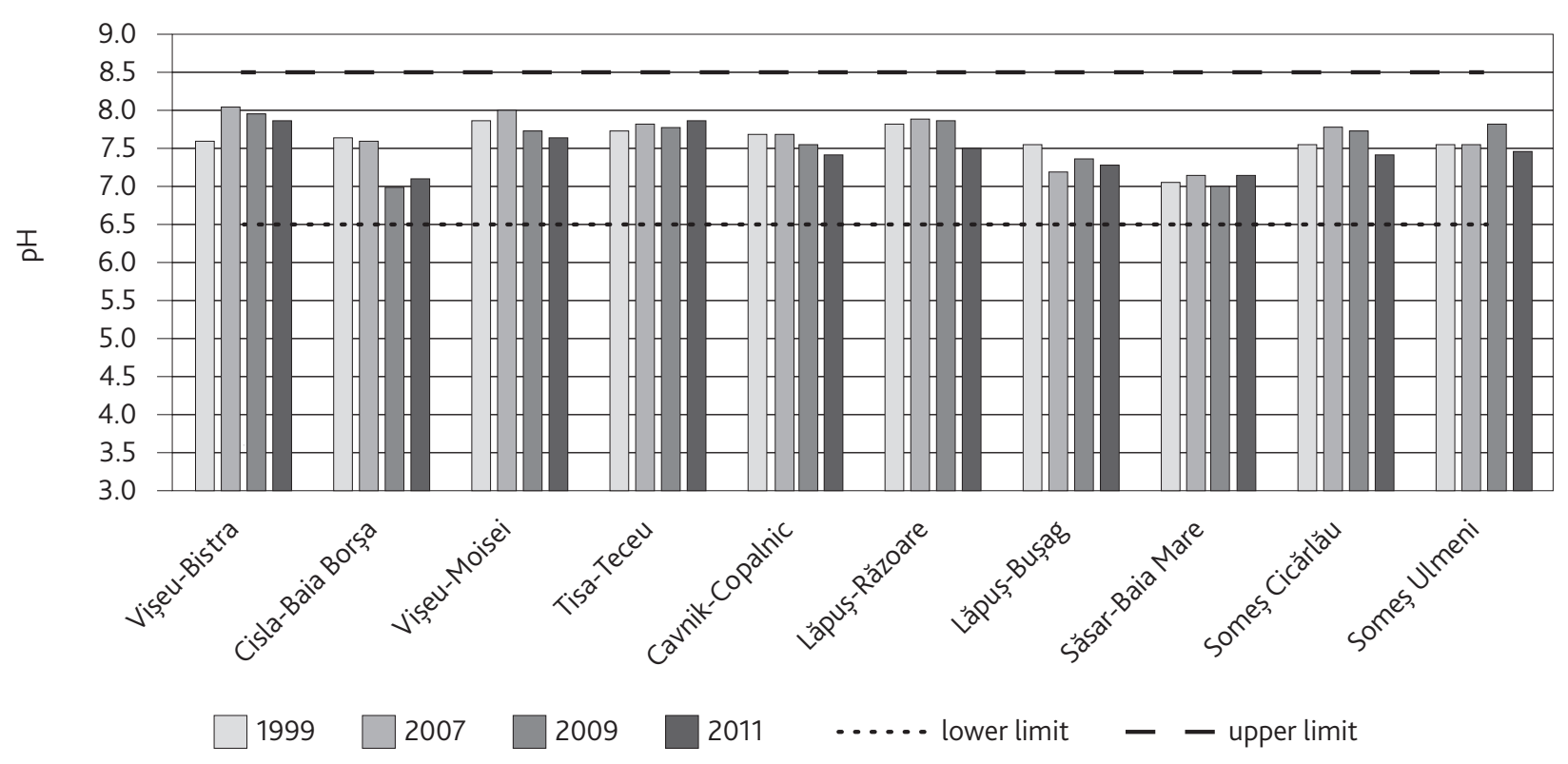

Figure 9. Concentration of $\mathrm{pH}$ in Tisa Basin and Someș Basin in 1999-2011 period

quality in the $5^{\text {th }}$ water quality class (Figure 7 ) (Minister Order no. 161/2006). This poor water quality might be due to discharging of unpurified water with heavy metals from the upstream mining exploitation and especially from the Baia Borşa Ore Processing Plant.

High cadmium concentrations are registered in sections from Someş hydrographic Basin on the Maramures County area, where except the Someş River at Ulmeni village section, in all investigated hydrographic sections the cadmium concentration leads the water in the $5^{\text {th }}$ water quality class (Figure 7) (Minister Order no. 161/2006). Similar results regarding the cadmium concentrations in the Somes Basin were achieved by Levei, et al., (2008) for Lăpuș, Cavnic and Săsar rivers.The presence of cadmium concentrations might be assigned to the wastewater discharge from the Ferneziu metallurgic plant (SC Romplumb SA) and upstream mining exploitations.

The nickel concentrations in the investigated hydrographic sections both for Tisa Basin and Someş Basin do not indicate a major alteration of water quality. The poorest water quality is registered for Cisla River downstream of Baia Borşa City hydrographic section where in 2007 the water was framed in the $4^{\text {th }}$ water quality class (Figure 8) (Minister Order no. 161/2006).

In the Someș Basin the highest concentrations for nickel are noticed for the Săsar River downstream of Baia Mare City where the $2^{\text {nd }}$ class of water quality is exceeded (Figure 8) (Minister Order no. 161/2006).

For all the ten investigated hydrographic sections, the water $\mathrm{pH}$ for all years taken into account (1999, 2007, 2009 and 2011) are framed between the lower and upper limits provided by Minister Order no. 161/2006 (Figure 9).
For Someș Basin rivers, similar results were obtained by Levei, et al., (2008) for Cavnic and Săsar rivers whose $\mathrm{pH}$ ranged between $6.85-7.45$ and $6.93-$ 7.85 , respectively.

\section{Conclusions}

To highlight the influence of the mining activities on the quality of the surface water in Maramures, research on ten hydrographic sections belonging to the Tisa hydrographic Basin and Someş hydrographic Basin were carried out for the years 1999, 2007, 2009 and 2011. From these ten hydrographical sections four sections belong to the Tisa Basin and six sections to the Someş Basin. These years are representative for the three major periods regarding the mining activity in Maramures County as follows: 1999 is for the full activity before the mining ban, 2007 is the year when the mining activity was banned, and 2009 and 2011 respectively are the representative years for the postmining shutdown period.

Although the mining activity has been banned since the end of 2006, according to the outcomes of the research, the water pollution phenomenon continued to increase in several places, especially in the Tisa Basin where the Cisla River downstream of Baia Borșa City is the most representative. This might be explained by the massive concentration of the mining perimeters around the Baia Borșa City (Cornu Nedeii, Dealul Negru, Burloaia, Gura Băii, Toroiaga mining exploitations), as well as by the uptake of wastewaters unpurified with sediments and heavy metals from mining waste dumps and Colbu, D1, D2, D 3 tailing ponds, and Baia Borşa ore Processing Plants). This situation is enhanced by 
the inadequate measures for proper shutdown and rehabilitation of mining perimeters and inefficient or under-capacity functioning of mining wastewater cleaning plants. Anyway, it is remarkable that in all hydrographic sections belonging to the Someş Basin in 2011 the heavy metals concentrations decreased, which might be explained by a better shutdown and rehabilitation measure application. The highest values of the heavy metal concentrations in the investigated sections in the Somes River basin belong to the Săsar section downstream of Baia Mare City. Similar results for $\mathrm{Cu}$ and $\mathrm{Pb}$ were obtained by Cordoș, et al., 2006 for upstream and downstream of the confluence of the rivers Somes and Lapus in 2001. This is due both to the influence of the Baia Mare mining perimeters (mine Săsar) and to those upstream such as Şuior mine, Baia Sprie mine, Herja mine and Centrală Ores Processing Plant. An interesting situation is noticed regarding the water $\mathrm{pH}$ for all investigated hydrographic sections. Even the metals concentrations are pretty high the water $\mathrm{pH}$ is alkaline within the limits $6.5-8.5$ provided by Minister Order no. 161/2006. This may be due one hand to the ineffective and improper functioning of the mining water cleaning plants and on the other hand to the intake of the fresh and clean tributaries. To reduce water pollution, most of the tailing ponds need better rehabilitation and conservation, including correction of the physical and chemical stability, as well as improvement of the drainage conditions. It is also necessary to endow every mining perimeter with a wastewater cleaning plant to discharge waters which meet the requirements provided by the legislation in force related to the quality of surface waters. It also requires ongoing monitoring of these waters in full compliance with the provisions of the Water Framework Directive 2000/60/EC whose major objective is to achieve the level of good ecological and chemical status of waters in the territory of the member states by the year in 2015 .

The results revealed by this paper could be used for extended researches and also by institutions and associations which evaluate the mining impact on the waters.

\section{Acknowledgements}

We would like to thank the National Company of the Precious and Base Metals "REMIN" S.A., Baia Mare and the Maramures Water Management System for their technical support data and information.

\section{References}

Bălănescu, S., Achim, V., Ciolte, A. 2002. The History of Management Mining, of Non-ferrous and Precious Metalurgy in Northern-Western of Romania, Gutinul Press, Baia Mare, 509 pp. (in Romanian).
Bird, G., Brewer, P.A., Macklin, M.G., Bălteanu, D., Șerban, M., Driga, B., Zaharia, S. 2008. River system recovery following the Novaț-Roșu tailings dam failure, Maramureș County, Romania, Applied Geochemistry 23, 3498-3518.

Bird, G., Brewer, P.A., Macklin, M.G., Bălteanu, D., Driga, B., Șerban, M., Zaharia, S. 2003. The solid state partitioning of contaminant metals and As in river channel sediments of the mining affected Tisa drainage basin, northwestern Romania and eastern Hungary, Applied Geochemistry 18, 1583-1595.

Cordoș, E., Rautiu, R., Roman, C., Ponta, M., Frentiu, T., Sarkany, A., Fodorpataki, L., Macalik, K., McCormick, C., Weiss, D. 2006. Characterisation of the rivers system in the mining and industrial area of Baia Mare, Romania, European Journal of Mineral Processing and Environmental Protection 3, 324335.

Dawson, E.J., Macklin, M.G. 1998. Speciation of heavy metals in floodplain and flood sediments: a reconnaissance survey of the Aire Valley, West Yorkshire, Great Britain. Environ. Geochem.Health 20, 67-76.

Kraft, C., Tumpling, W., Zachmann, D.W. 2006. The effects of mining in Northern Romania on the heavy metal distribution in sediments of the rivers Szamos and Tisza (Hungary). Acta hidrochim.hydrobiol. 34, 257-264.

Levei E.A., Şenilă M., Miclean M., Roman C., Abraham B., Cordoş E. 2008. Surface water pollution with heavy metals in Baia Mare mining basin, 15th International Congress of the International Soil Conservation Organization „Soil and Water Conservation, Climate Change and Environmental Sensitivity" Budapest, Hungary, 18-23 May 2008, Proceedings Volume ISBN 978-963-9545205, Published by the Geographical Research Institute, Budapest, Hungary, $287 \mathrm{pp}$.

Macklin, M.G., Brewer, P.A., Hudson-Edwards, K.A., Bird, G., Coulthard, T.J., Dennis, I.A., Lechler, P.J., Miller, J.R. , Turner, J.N. 2006. A geomorphological approach to the management of rivers contaminated by metal mining, Geomorphology 79, 423-447.

Macklin, M.G., Brewer, P.A., Bălteanu, D., Coulthard, T.J., Driga, B., Howard, A.J., Zaharia, S. 2003. The long term fate and environmental significance of contaminant metals released by the January and March 2000 mining tailings dam failures in Maramures, County, upper Tisa Basin, Romania, Applied Geochemistry 18, 241-257.

Miller, J.R. 1997. The role of fluvial geomorphic processes in the dispersal of heavy metals from mine sites., J. Geochem.Explor 58, 101-118.

Posea, Gr., Moldovan, C., Posea, A. 1980. Homeland counties. Maramureș County, Socialist Republic of Romania Press, Bucharest, 176 pp. (in Romanian). 
Retegan, I., Bandula, O., Grigorescu, M., Husian, M., Nădişan, I. 1980. Counties Homeland, Maramuresmonography, Sport-Turism Press, 330 pp. (in Romanian).

Roman, C., Pavelescu, G., Miclean, M., Savastru, D., Levei, E., Pfeiffer, E. 2008. Influences of the mining activities on the heavy metal pollution in Somes River, North-Western Romania, Proc. 4th European Bioremediation Conf., ID 085, 3-6 Septembrie 2008, 1-5.

Sima, M., Zobrist, J., Șenilă, M., Levei, E-A., Bela, A., Dold, B., Bălteanu, D. 2008. Environmental pollution by mining activities - A case study in the Criş Alb Valley, Western Carpathians, Romania, GeoEcoMarina 14, 9-20.

Smical, I., Muntean, A., Bud, I., Arad, V. 2013. Research on the influence of the local mining activities on the sediments quality of Băiţa Valley in Maramureş County, România, Recent Advances in Civil and Mining Engineering, Proceedings of the 4th European Conference of Civil Engineering (ECCIE '13), Proceedings of the 1st European Conference of Mining Engineering, (MINENG '13) Antalya, Turkey, October 8-10, 2013, ISSN: 22274588, ISBN: 978-960-474-337-7, 278-284.

Ujvári, I. 1972. Water Geography of Romaia, Scientific Press, Bucharest, 592 pp. (in Romanian).

Vasilescu, I., Smical, I., Pop, I. 2012. The Impact of Mining Industry on the Landscape of Maramures, County, Participation in the sixth edition of the International Symposium „Actual Environment \& Sustainable Development”, Iași, 14th -16th October 2011, published in "Present Environment and Sustainable Development", vol 6 (2), 253-26o.

Zobrist, J., Sima, M., Dogaru, D., Șenilă, M., Yang, H., Popescu, C., Roman, C., Bela, A., Frei, L., Dold, B., Bălteanu, D. 2009. Environmental and socioeconomic assessment of impacts by mining activities - a case study in the Certej River catchment, Western Carpathians, Romania, Environ Sci Pollut Res. 16, (Suppl 1), S14-S26.
*** Directive 2000/60/EC of the European Parliament and of the Council of 23 October 2000 establishing a framework for Community action in the field of water policy, Official Journal of the European Communites, Volume 43, ISSN 0378-6978.

*** Government Decision no. 997 of 29 September 2010 approving the permanent closure and post-closure monitoring of the security status of the target and the environmental factors of mines and quarries, stage XI, and change some laws in closures of mines and quarries, published in Of. M. no. 692/15 oct. 2010 (in Romanian).

*** Ministry of Environment, 1992. Cadastre Atlas of Water from Romania - Part 1 Morpho-hydrographic Data on the Hydrographical Network, Aquaproiect S.A., Bucharest, pp. 695 (in Romanian).

*** Ministry of Economy, 2014. „,The Strategy of Mining Industry, for 2012-2035 period", (http://www. minind.ro/resurse_minerale/Strategia_Industriei_ Miniere_2012_2035.pdf) (in Romanian).

*** National Company of the Precious and Base Metals

"REMIN" S.A., (NCPBM Remin SA), 2014. Technical data and information. (in Romanian).

*** Minister Order no. 161 of 16 February 2006 the Minister of Environment and Water for approving the Norms concerning the classification of surface water quality to determine the ecological status of water bodies, published in M.Of. no. 511/13th Jun. 2006 (in Romanian).

*** SR EN ISO 15586:2004 Determination of trace elements by graphite oven atomic absorption.

*** SR EN ISO 5961:2002 Determination of cadmium by atomic absorption spectrometry.

*** SR ISO 8288:2001 Water Quality. Determination of cobalt, nickel, copper, zinc, cadmium, lead. Method using flame atomic absorption spectrometry.

*** SR ISO 9174:1998 Determination of chromium. Atomic absorption method.

*** SR 8662-2:1997 Water Quality. Determination of manganese. Atomic absorption spectrometric method.

*** SR 13315:1996 Water Quality. Determination of iron. Atomic absorption spectrometric method. 